\title{
PROCESSING METHODS AND STORAGE PERIOD AFFECT THE QUALITY OF PALM OIL
}

\author{
Enyi Chukwunwike U. ${ }^{1}$, Ojimelukwe Philippa C. ${ }^{1 凶}$ \\ ${ }^{1}$ Michael Okpara University of Agriculture Umudike, College of Applied Food Sciences and Tourism, \\ Department of Food Science and Technology, P.M.B 7267 Umuahia, Abia State Nigeria. \\ هphilippaco60@gmail.com \\ https://doi.org/10.34302/crpjfst/2021.13.4.15 \\ Article history: \\ Received: \\ 27 August 2021 \\ Accepted: \\ 23 October 2021 \\ Keywords: \\ Palm oil; \\ Nutrient quality; \\ Processing methods; \\ Storage period; \\ Indices of fat deterioration

\section{ABSTRACT} \\ The effects of processing methods and storage periods on oil palm quality \\ were studied in this research. The palm fruits were subjected to four different \\ processing methods; boiling (B), soaking followed by boiling (SWB), \\ steaming (ST) and extraction with petroleum ether (SP). Quality indices, \\ functional; physical properties and selected vitamins were determined. The \\ results showed that free fatty acid values ranged from 5.14 in SP to 6.54 \\ $\mathrm{mg} / \mathrm{KOH} / \mathrm{g}$ in SWB: peroxide value from 2.67 in SP to $10.07 \mathrm{meq} / \mathrm{kg}$ in \\ SWB, saponification value from 194.48 in ST to $196.82 \mathrm{mg} / \mathrm{KOH} / \mathrm{g}$ in SWB; \\ iodine value from 49.07 in SP-52.24g/100g in SWB. Free fatty acid, \\ peroxide and iodine values increased as storage time increased except for \\ saponification value which decreased. The moisture content value was from \\ $0.17-0.35 \%$, specific gravity $\left(0.89-0.92 \mathrm{~g} / \mathrm{cm}^{3}\right)$; smoke point $(231.67-$ \\ $\left.240.00^{\circ} \mathrm{C}\right)$, flash point $\left(294.00-303.00^{\circ} \mathrm{C}\right)$ and fire point $\left(297.33-309.33^{\circ} \mathrm{C}\right)$. \\ The soaked and boiled sample (SWB) had the highest values in moisture, \\ smoke and flash point. While steaming (ST) induced the highest values in \\ specific gravity and fire point. The sample extracted with petroleum ether \\ had the lowest values for all the physical properties determined and the \\ highest values for vitamins A (718.97IU/100g) and E (43.95IU/100g. The \\ boiled sample (B) had the lowest values for vitamin A (699.47IU/100g) and \\ vitamin E (38.87IU/100g). Both vitamins decreased as storage time \\ increased. Moisture content and specific gravity increased while smoke, \\ flash and fire points decreased as storage time increased. Emulsion capacity \\ ranged from $62.19-100 \%$ and emulsion stability ranged from $42.70-100 \%$. \\ Steaming method (ST) produced oil samples with the highest values for both \\ emulsion capacity and stability while extraction with petroleum ether had \\ the lowest values. Both emulsion stability and emulsion capacity increased \\ as storage time increased. Extraction with petroleum ether was the best in \\ terms of good quality, followed by steaming and boiling methods.
}

\section{Introduction}

The Oil palm (Elaeis guineesis) is a plant that produces very high quantities of oil. Its oil yield is about 3.5 tonnes of oil/ha/year (Ngando et al., 2011). The Oil palm is believed to originate from West Africa. Both the oil from the fruit and the kernel are edible and commercially important. Palm oil is obtained from the fresh mesocarp while palm kernel oil is obtained from the kernel (Poku, 2002). World consumption of palm oil was more than 16.7 million tonnes in 1997/1998 and over 40 million tonnes in 2007/2008. This figure was projected to increase to 70 million tonnes or more by 2020 (Grapevine, 2008). The chemical compositions and physical properties of palm oil and palm kernel oils vary. Both may be used in food and non-food industries (Gan Peck Yean, 2012). The oil has the same proportion of unsaturated to 
saturated fatty acids, making it unique for many commercial purposes without need for adjusting the processes (Sugano and Tsuji, 1997).

Fresh red palm oil is very healthy for human use since it contains a good proportion of saturated to unsaturated fatty acids and is rich in antioxidants like beta-carotene, tocotrienols, tocopherols, plant squalene, and phytosterol (Oguntibeju et al., 2009). It is rich in 16 carbon saturated fatty acids, palmitic acid, monounsaturated oleic acid and linoleic acid (omega-6 fatty acid) (10\%) (Analava and Sutapa, 2009). Palm oil has a unique natural combination of phytonutrients that cannot be found in other vegetable oils (Ahsan et al., 2015). Its minor components which constitutes about $1 \%$ includes carotenes, vitamin E, sterols, pigments, and fatty acids (Embrandiri et al., 2013).

The oil is light yellow or red in colour because of its high content of carotenoids some of which are precursors of vitamin A (Ugwu et al., 2002). It is one of the most popularly consumed oil in the world (Bazlul et al., 2010). By- products of palm oil processing include palm kernel, palm kernel cake, palm frond, palm trunk and palm bunch. These by-products have numerous uses. Palm oil is mainly used for human consumption, animal feed and other industrial applications. Nigerians use palm oil as a major cooking oil. It is therefore a good source of energy in the diet (Babatunde, 1987). The free fatty acid (FFA) content, moisture, saponification value and peroxide value are indices of palm oil quality (Madubuike et al., 2015). Fresh palm oil contains high amounts of vitamins $\mathrm{A}$ and $\mathrm{E}$. It is extensively used across the world today (up to $33 \%$ ); followed by soya oil with 31\% (I.C.E.X, 2014). Palm oil especially the stearin and olein fractions may be directly blended with other oils to improve oxidative stability (De Marco et al., 2007). It may be inter-esterified with other oils in order to meet the trans-free fat requirements of the food industry (Gee, 2007).

Palm oil is the richest dietary source of betacarotene and contains a total of $\sim 500-800 \mathrm{mg}$ of carotenoids $/ \mathrm{kg}$ oil, which is $\sim 15$ times higher than the carotenoid content of carrot (Sundram et al., 2003). The quality of palm oil determines its application. It is also related to the processing method. In Nigeria, the traditional (mostly manual), semi-mechanized and mechanized processors are major methods used in the oil processing industry (Web 1). To a large extent, small holders/traditional processors dominate the sector accounting about for $80 \%$ (Izah and Ohimain, 2013).

This study will investigate the quality of palm oil processed using four different methods. The research will provide information on the best processing method for producing good quality palm oil which can be adopted by small scale palm oil processors.

\section{Materials and methods}

\subsection{Sample collection and preparation}

Palm fruit was harvested by cutting with sharp knives when fully ripened from Egede in Udi Local Government Area of Enugu State. The palm fruits were subjected to four different processing methods; boiling (B), soaking before boiling (SWB), steaming (ST) and cold extraction with petroleum ether (SP). Five kg each of the harvested fruits were used for each of the different processing methods. Scheme 1 describes the processing of palm fruits.

In all the methods, five (5) $\mathrm{kg}$ of the fresh fruit were harvested and heaped on the ground for two days after which they were threshed to free the fruit from the bunch. In the boiling (B) and soaking with boiling (SWB) methods, the palm fruits were parboiled in water in the ratio of 1:2 in a cooking pot for 30 minutes and then pounded in a wooden mortar to separate pulp and nuts. The nuts (palm kernels) were removed and the pulp manually squeezed to obtain a red viscous fluid (oil, fiber, water, impurities), which was heated for 30 minutes for traces of water to evaporate and was finally sieved using metal basket to obtain a clear red palm oil. The processed palm oil was stored in an air tight plastic container at room temperature (30 ${ }^{\circ} \mathrm{C}$ ) until needed for analysis. In steaming method (ST), the same quantity of the fresh fruit bunches was harvested and treated as in the boiling method. The palm fruits were steamed using a steaming pot which was constructed in 
such a way that during steaming, the palm fruits do not touch the water aided by separating the fruit from the water with a wire sieve. The fruits were steamed for 30 minutes and then ground in a locally constructed machine until pulp and nuts were obtained. The nuts were removed and the pulp was treated as in the other processing methods. The processed palm oil was stored in an air tight plastic container at room temperature $\left(30^{\circ} \mathrm{C}\right)$ until needed for analysis.

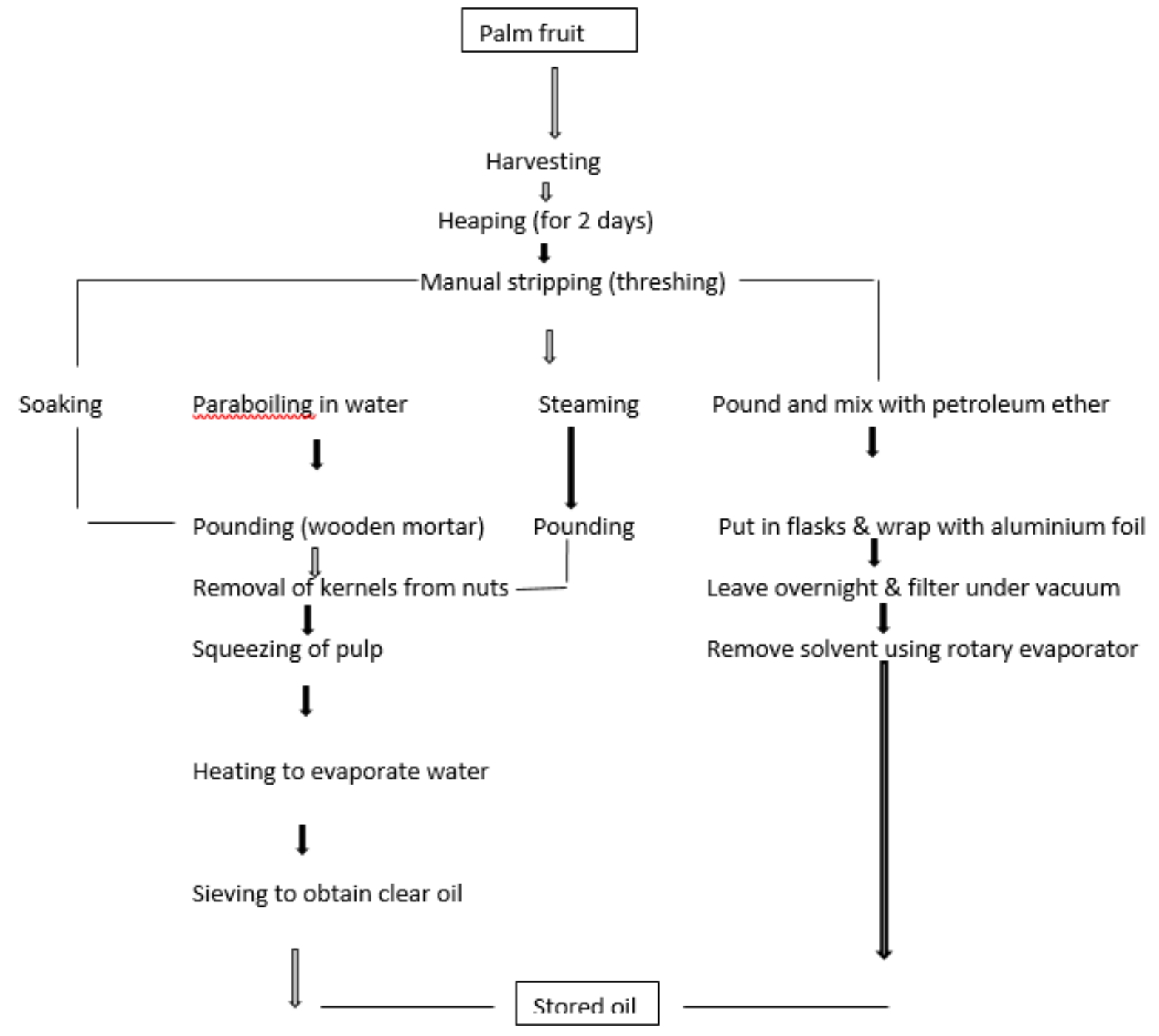

Scheme 1. Processing of palm fruits

In extraction with petroleum ether (SP), the samples were collected for extraction of the oil according to the method by Alina et al. (2012). Petroleum ether (b.pt $40-60^{\circ} \mathrm{C}$ ) was used as the extraction solvent. The ratio of the quantity of oil samples to petroleum ether used was 1:3. Forty (40) $g$ of the ground sample was homogenized with $120 \mathrm{ml}$ of petroleum ether and left overnight. The flasks used were wrapped with aluminum foil to avoid the samples from being exposed to the light. It was subsequently filtered under vacuum through a filter paper (Whatman No.1) in Buchner a funnel to remove the ground fiber from the solvent. The filtrate was then transferred into round bottom flask and attached to a rotary evaporator (Model R-300). The petroleum ether solvent was removed after extraction at $40{ }^{\circ} \mathrm{C}$. The extracted palm oil was stored in an air tight plastic container at room temperature $\left(30{ }^{\circ} \mathrm{C}\right)$ until needed for analysis. Freshly extracted palm oil 
and samples stored for 30, 60 and 90 days were used for analysis.

In all the methods, five (5) $\mathrm{kg}$ of the fresh fruit were harvested and heaped on the ground for two days after which they were threshed to free the fruit from the bunch. In the boiling (B) and soaking with boiling (SWB) methods, the palm fruits were parboiled in water in the ratio of $1: 2$ in a cooking pot for 30 minutes and then pounded in a wooden mortar to separate pulp and nuts. The nuts (palm kernels) were removed and the pulp manually squeezed to obtain a red viscous fluid (oil, fiber, water, impurities), which was heated for 30 minutes for traces of water to evaporate and was finally sieved using metal basket to obtain a clear red palm oil. The processed palm oil was stored in an air tight plastic container at room temperature (30 ${ }^{\circ} \mathrm{C}$ ) until needed for analysis. In steaming method (ST), the same quantity of the fresh fruit bunches was harvested and treated as in the boiling method. The palm fruits were steamed using a steaming pot which was constructed in such a way that during steaming, the palm fruits do not touch the water aided by separating the fruit from the water with a wire sieve. The fruits were steamed for 30 minutes and then ground in a locally constructed machine until pulp and nuts were obtained. The nuts were removed and the pulp was treated as in the other processing methods. The processed palm oil was stored in an air tight plastic container at room temperature $\left(30^{\circ} \mathrm{C}\right)$ until needed for analysis.

In extraction with petroleum ether (SP), the samples were collected for extraction of the oil according to the method by Alina et al. (2012). Petroleum ether (b.pt $40-60^{\circ} \mathrm{C}$ ) was used as the extraction solvent. The ratio of the quantity of oil samples to petroleum ether used was 1:3. Forty (40) $\mathrm{g}$ of the ground sample was homogenized with $120 \mathrm{ml}$ of petroleum ether and left overnight. The flasks used were wrapped with aluminum foil to avoid the samples from being exposed to the light. It was subsequently filtered under vacuum through a filter paper (Whatman No.1) in Buchner a funnel to remove the ground fiber from the solvent. The filtrate was then transferred into round bottom flask and attached to a rotary evaporator (Model
R-300). The petroleum ether solvent was removed after extraction at $40{ }^{\circ} \mathrm{C}$. The extracted palm oil was stored in an air tight plastic container at room temperature $\left(30^{\circ} \mathrm{C}\right)$ until needed for analysis. Freshly extracted palm oil and samples stored for 30,60 and 90 days were used for analysis.

\subsection{Determination of oil yield}

The $\%$ yield of oil was calculated using the formula given as follows:

$$
Y=\frac{M e}{M m} \times \frac{100}{1}
$$

Where: $\mathrm{Y}=$ oil yield, $\mathrm{Me}=$ mass of oil extracted, $\mathrm{Mm}=$ mass of loose fresh fruit.

\subsection{Determination of Vitamins}

The colorimetric and Futher-Meyer methods of the Association of Vitamin Chemists described by Kirk and Sawyer (1991) was used to determine Vitamins A and $\mathrm{E}$.

\subsection{Determination of quality indices}

The free fatty acid, peroxide, iodine and saponification values were determined using the AOAC method (2005).

\subsection{Determination of physical properties}

Smoke and flash points were determined according to the method described by Pike (2003). The moisture content and specific gravity of the oil were determined by the AOAC method (2005).

\subsection{Determination of functional properties}

The emulsion capacity and stability of the oil was determined by the method described by Yasumatsu et al. (1972).

\subsection{Data Analysis}

Analysis of variance was used to determine significant differences $(p<0.05)$ among treatment means. Mean separation was done using the SPSS version 20.0. Separation of means was carried out by Duncan Multiple range test and values were reported as means and standard deviation. 


\section{Results and discussions}

Figure 1 shows the yield of oil from the four processing methods. The oil yield ranged from $14.00 \%$ (SWB) - $19.60 \%$ (SP). Extraction with petroleum ether (SP) had the highest oil yield $(19.60 \%)$.

The variations in the oil yield for the four processing methods adopted could be as a result of the ability of the different methods applied to loosen the matrix of the plant tissues to allow fat extraction.

According to Owolarafe et al. (2002), during digestion, the cells are completely ruptured and lose their integrity to release the oil.

When digestion is properly done, a homogenous mash without undigested fruits is formed. This enhances oil yield (Aletor et al., 1990).

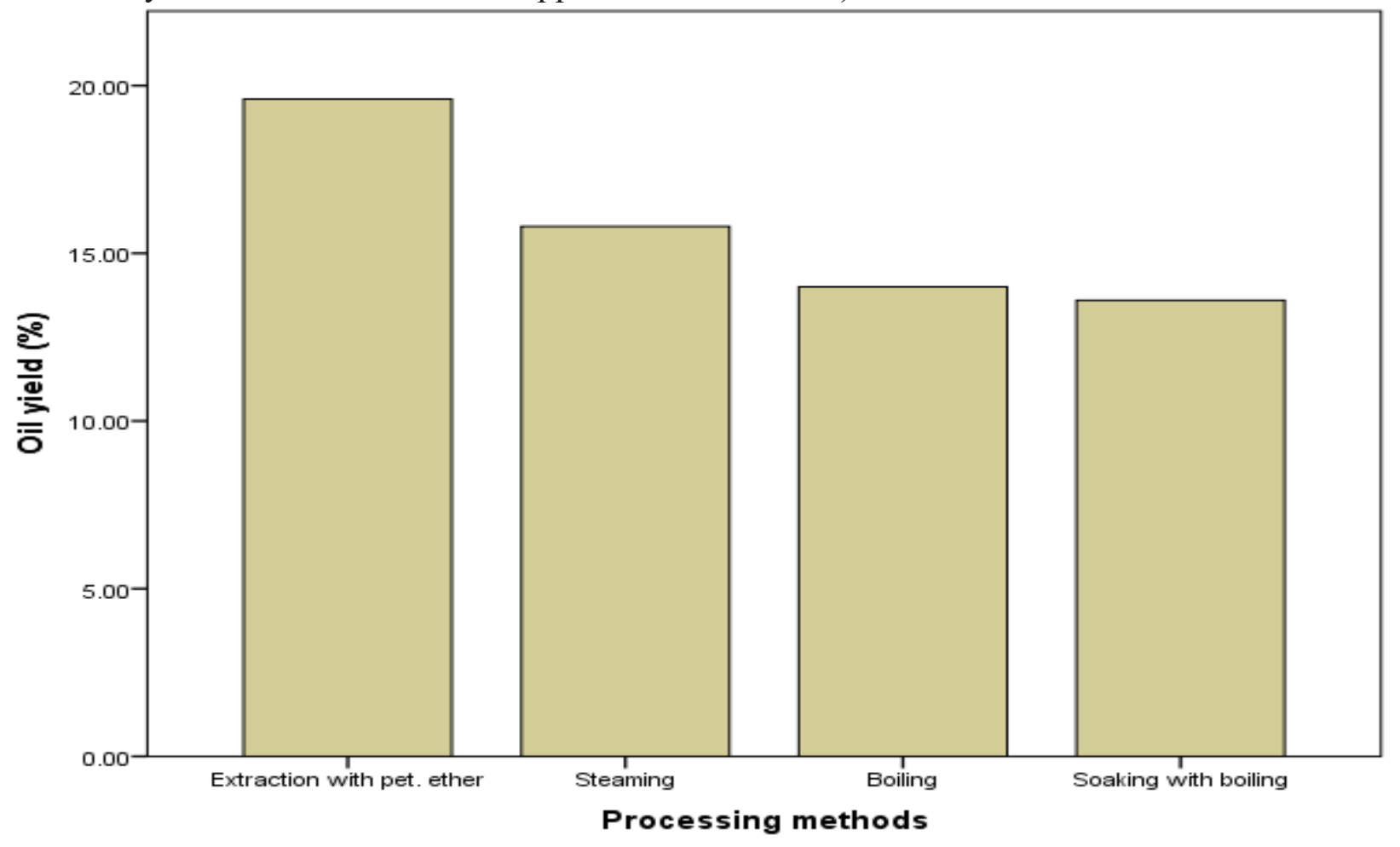

Figure 1. Effects of processing methods on oil yield

\subsection{Physical properties of palm oil}

The moisture contents of the processed palm oils are shown in the Figure 2. The moisture content for freshly extracted oil samples ranged from 0.17 (SP) $-0.35 \%$ (SWB). Samples ST, B and SWB were statistically similar $(\mathrm{p}>0.05)$. The higher moisture content recorded in SWB could be as a result of the processing method applied where the fruits were soaked in water over night before parboiling. The moisture contents of the fresh palm oil $(0.17-0.35 \%)$ was higher than the recommended limit $(0.10 \%)$ (Aletor et al., 1990). Ngando et al. (2011) reported $0.22 ; 0.23-0.32$ and 0.08 moisture content for of palm oil produced in Cameroun using traditional, semi-mechanized and mechanized methods. $\mathrm{Zu}$ et al. (2012) reported the moisture content of palm oil produced in Ghana as $0.79-1.59 \%$. Udensi and Iroegbu (2007) reported $0.14-0.60 \%$ as the moisture content of fresh palm oil sold in main market of Abia State Nigeria which is similar to the result of this study. Agbaire (2012) reported 0.14 $0.17 \%$ as the moisture content of palm oil sold in Delta state, Nigeria which is also close to the result of this study. After 30 days of storage, the moisture content of palm oils from the four processing methods ranged from 0.39 (SP) $0.93 \%$ (SWB). There were significant $(p<0.05)$ differences in the moisture content values. After 60 days of storage, the moisture contents of palm oil samples from the four processing methods ranged from 0.46 (SP) $-1.34 \%$ (SWB). There 
were significant $(\mathrm{p}<0.05)$ differences among the moisture contents of the samples. After 90 days of storage, the moisture contents of palm oil samples from the four processing methods ranged from $0.62(\mathrm{SP})-1.56 \%(\mathrm{SWB})$. There were also significant $(\mathrm{p}<0.05)$ differences among the moisture contents of the samples.

High moisture content promotes rancidity, aids spoilage and short shelf-value while low moisture content promotes stability during storage of palm oil samples. According to Poku (2002) and Orji and Mbata (2006) the moisture content of palm oil depends directly on the final extraction and clarification processes. Moisture contents of the fresh and stored palm oil fell within the limiting range of $0.09-3.1 \%$ reported by Denenu and Eze (1983) as acceptable standard which will not cause refining and storage problems. Recommended safe moisture content for fresh oil as reported by SON (2000) and NIS (1992) is $0.29 \%$. The differences observed in the moisture content of the fresh palm oil for samples B and SWB could be as a result of the processing methods adopted. Moisture content observed in all the samples during storage were within the acceptable standards with the exception of samples processed using boiling and soaking /boiling when they were stored for $60-90$ days $(1.06 \%$, $1.22 \%$ and $1.34 \%, 1.56 \%$ respectively as shown in Figure 2). The recommended maximum safe moisture level for palm oil storage is $1 \%$.

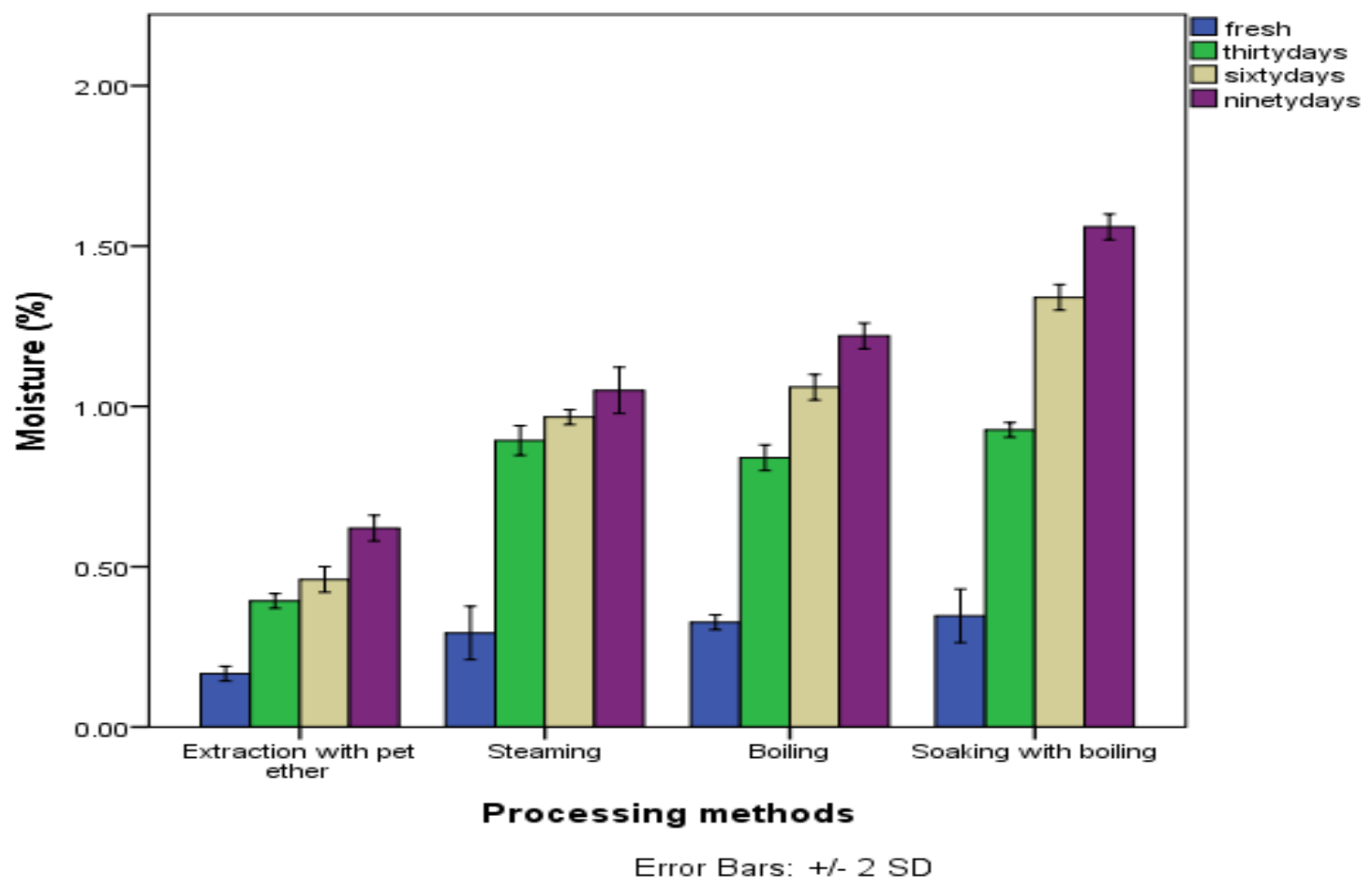

Figure 2. Changes in moisture content of palm oil during the storage period of 90 days

The specific gravity values of the processed palm oils are shown in Table 1. The specific gravity for freshly prepared oil sample for the four processing methods ranged from $0.89-0.92 \mathrm{~g} / \mathrm{cm}^{3}$ Sample SP had the least value $\left(0.89 \mathrm{~g} / \mathrm{cm}^{3}\right)$ while sample B had the highest value $\left(0.92 \mathrm{~g} / \mathrm{cm}^{3}\right)$. Samples B and SWB were statistically similar. During storage, the palm oil samples maintained the same specific gravity values after an initial rise within the 30 days of storage. There were no significant $(p>0.05)$ differences among samples SP, ST and B within the first 30 days of storage and also for all the processing methods for 60 and 90 days of storage.

Udensi and Iroegbu (2007) reported 0.83 $-0.88 \mathrm{~g} / \mathrm{cm}^{3}$ as the specific gravity of palm oil sold in key markets of Abia State, Nigeria. 
Agbaire (2012) reported $0.859-0.885 \mathrm{~g} / \mathrm{cm}^{3}$ as the specific gravity of palm oil sold in key markets of Delta state. The specific gravity of the palm oil showed that palm oil is less dense than water, therefore will float. The values obtained were very much close to the standard range of $0.898-0.907 \mathrm{~g} / \mathrm{cm}^{3}$ approved by Standard Organization of Nigeria (SON) (2000).

Table 1. Changes in specific gravity of the palm oil stored for 90 days $(B=$ Boiling; $S W B=$ Soaking before boiling; $\mathrm{ST}=$ Steaming; $\mathrm{SP}=$ Cold extraction with petroleum ether. Values with different superscript down the column are significantly different $(\mathrm{p}<0.05))$

\begin{tabular}{|c|c|c|c|c|}
\hline Sample & Fresh & 30 days & 60 days & 90 days \\
\hline SP & $0.89 \mathrm{a}$ & $0.92 \mathrm{a}$ & $0.92 \mathrm{a}$ & $0.92 \mathrm{a}$ \\
\hline ST & $0.91 \mathrm{c}$ & $0.92 \mathrm{a}$ & $0.92 \mathrm{a}$ & $0.92 \mathrm{a}$ \\
\hline B & $0.92 \mathrm{~b}$ & $0.92 \mathrm{a}$ & $0.92 \mathrm{a}$ & $0.92 \mathrm{a}$ \\
\hline SWB & $0.91 \mathrm{c}$ & $0.92 \mathrm{a}$ & $0.92 \mathrm{a}$ & $0.92 \mathrm{a}$ \\
\hline
\end{tabular}

Values shows the mean of triplicate analysis and \pm standard deviation. Values with different superscript down the column are significantly different $(\mathrm{p}<0.05)$. $\mathrm{SP}=$ Solvent extraction; $\mathrm{ST}$ $=$ Steaming; $\mathrm{B}=$ Boiling; SWB = Soaking followed by boiling.

The smoke point of the processed palm oils are shown in the Figure 3.The smoke point for the fresh and stored palm oil for the four processing methods ranged from 231.67 (SP) $240.00^{\circ} \mathrm{C}(\mathrm{SWB})$. There were no significant $(p>0.05)$ differences between samples ST and B for freshly prepared palm oil; amongst samples ST, B and SWB after 30 days of storage; between samples SP and B and also between samples ST and SWB after 60 days of storage and between samples SP, B and SWB after 90 days of storage. Smoke point is the temperature at which a fat or oil produces a constant wisp of smoke when heated. It is a useful index of the suitability for frying. The Canadian specifications indicate that frying oil should have a smoke point above $200^{\circ} \mathrm{C}$ (Appelqvist and Ohlson, 1972). Figure 3 indicates that the processed palm oils fulfilled this requirement and can be used as a frying oil.

The flash point of the processed palm oils are shown in the Figure 4 . The flash point for the fresh and stored palm oil for the four processing methods ranged from 294.00 (SP) $303.00^{\circ} \mathrm{C}(\mathrm{SWB})$. There were no significant
( $>0.05$ ) differences among samples ST, B and SWB for freshly prepared oil sample; samples B and SWB after 60 days of storage and samples ST and B after 30 and 90 days of storage. The Flash point is the temperature at which the decomposition products produced from frying oils can be ignited. This temperature ranges from $275^{\circ} \mathrm{C}-330{ }^{\circ} \mathrm{C}$ for different oils and fats according to Canadian specifications (Appelqvist and Ohlson, 1972). The fire point of the processed palm oils are shown in the figure 5.The fire point for the fresh and stored palm oil form the four processing methods ranged from 297.33 (for SP) $-308.67^{\circ} \mathrm{C}$ (for SWB). There were no significant $(\mathrm{p}>0.05)$ differences between the fire points of samples ST and SWB for freshly prepared samples.

After 30 and 60 days of storage, there were no significant $(\mathrm{p}>0.05)$ differences between samples SP and SWB as well as ST and B. There were no significant $(p>0.05)$ differences between samples ST and B after 90 days of storage. The Fire point is the temperature at which oil combustion is sustained.

The high value obtained for these physical properties indicate that palm oil is suitable for frying. These physical parameters decreased with increase in storage time. This could result from active lipase present in the palm oil which causes the hydrolysis of triacylglycerols to fatty acid and glycerol thereby increasing the free 
fatty acid content which impairs oil quality and subsequently affects the frying quality of the oil.

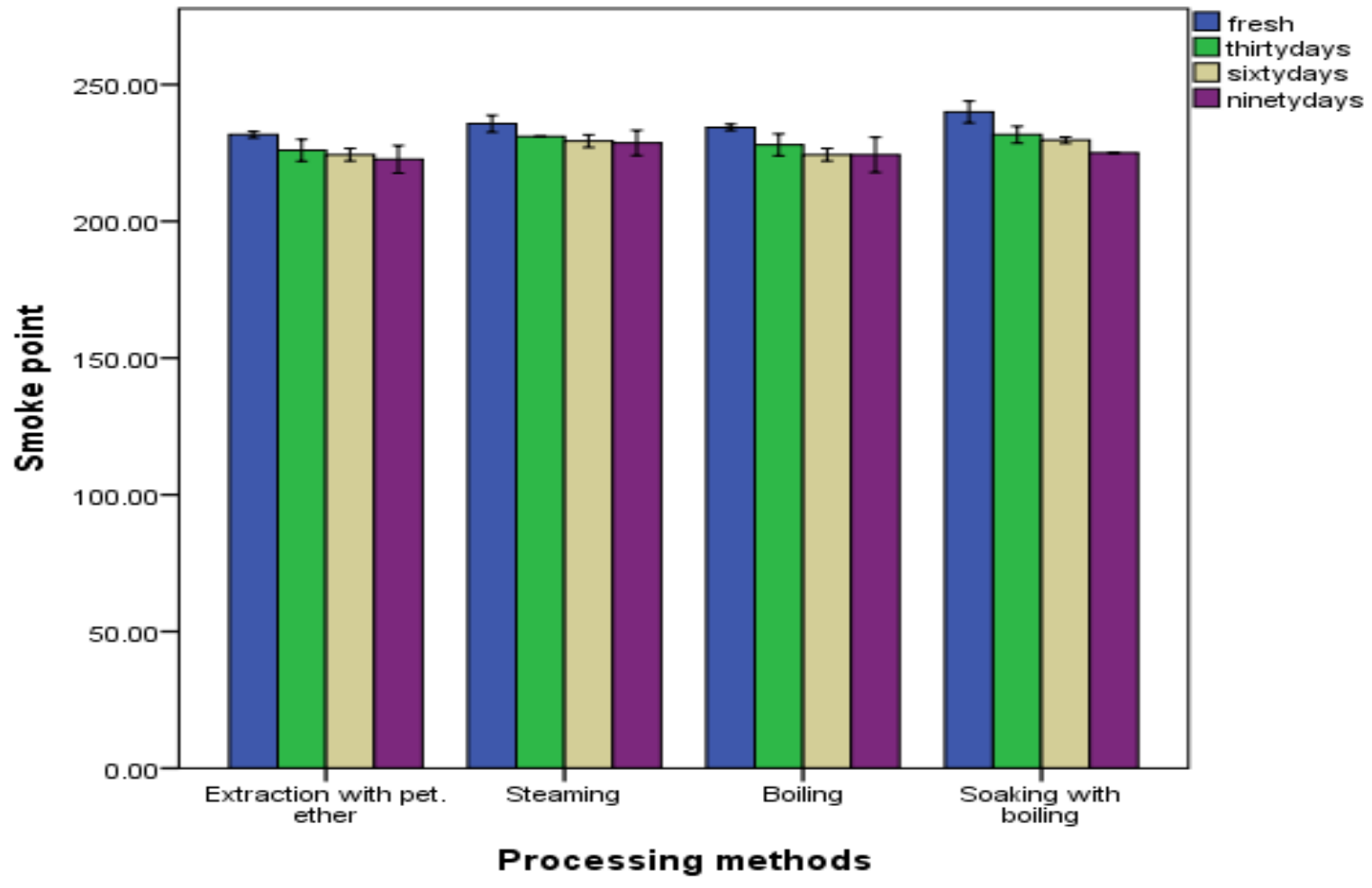

Error Bars: +/- $2 \mathrm{SD}$

Figure 3. Changes in smoke point of palm oil during the storage period of 90 days

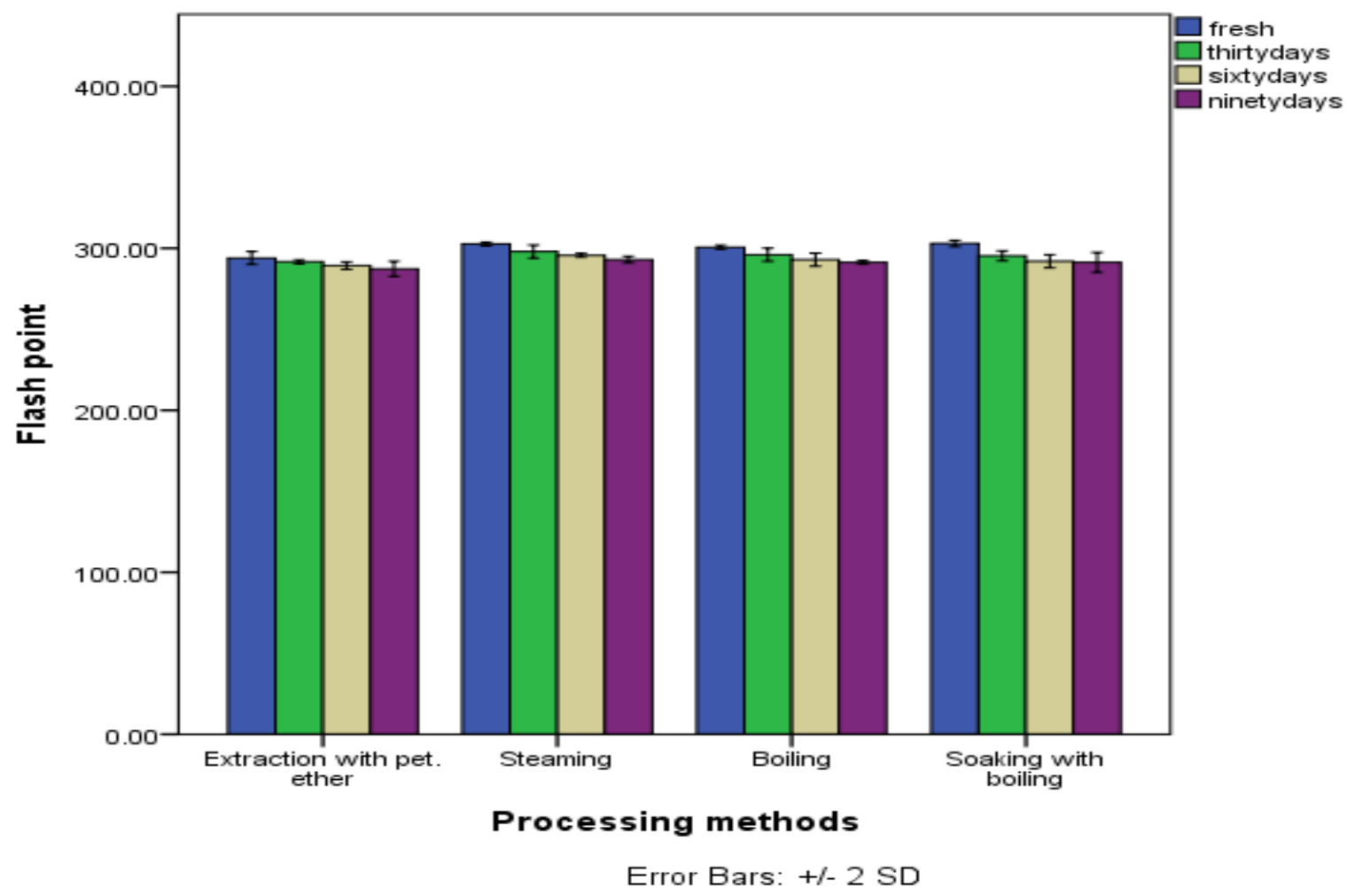

Figure 4. Changes in flash point of palm oil during the storage period of 90 days 


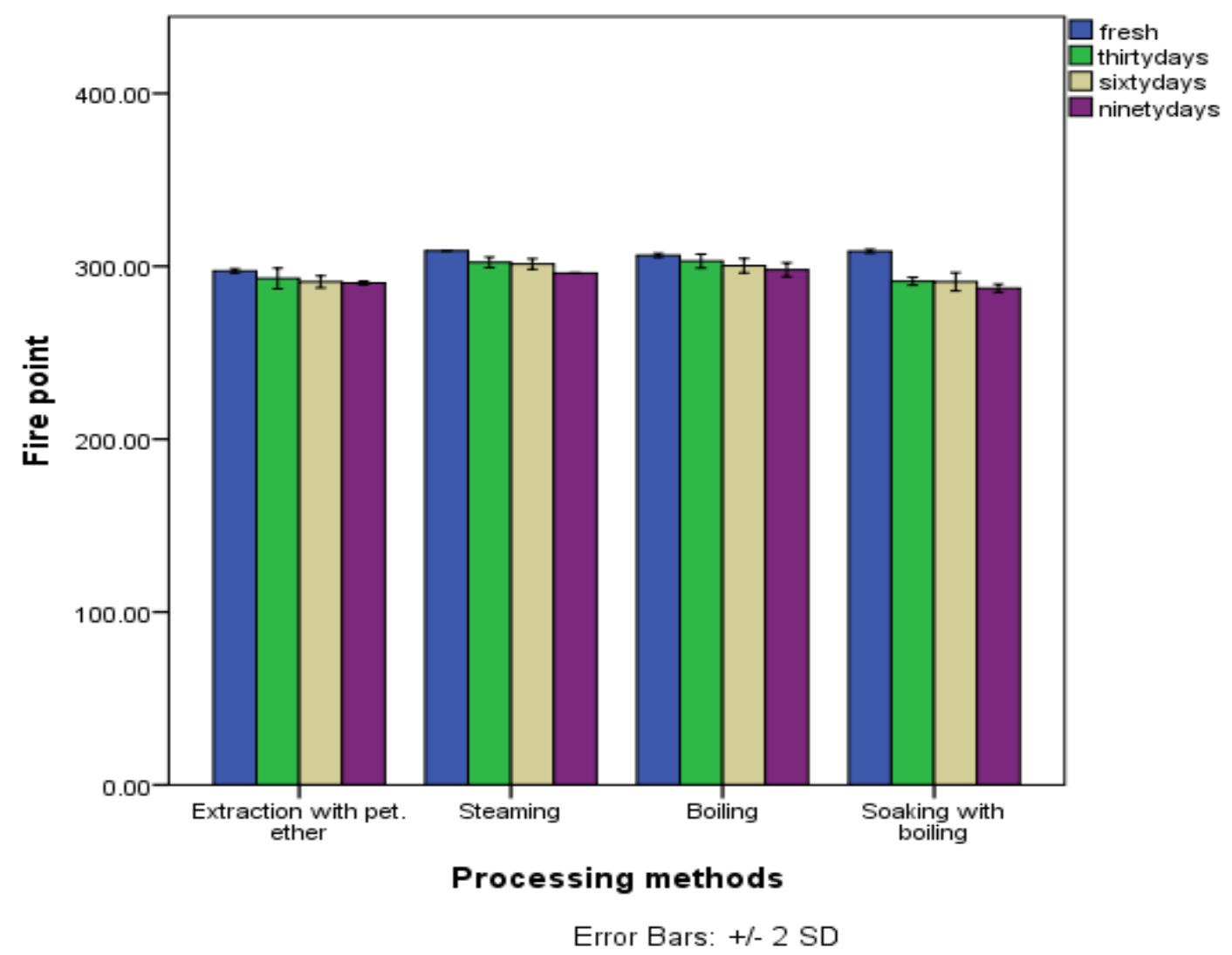

Figure 5. Changes in fire point of palm oil during the storage period of 90 days

\subsection{Functional properties of the processed palm oil}

The emulsion capacity of oil samples from the various processing methods are shown in Figure 6. The emulsion capacity for freshly prepared oil samples ranged from 62.19 (for SP) - $100.00 \%$ (for ST). After 30 days of storage, the emulsion capacity of the oil samples ranged from 68.62 (for SP) - $100.00 \%$ (for ST). After 60 days of storage, the emulsion capacity of the oil samples from the four processing methods ranged from 74.63 (for SP) $-100.00 \%$ (for ST). After 90 days of storage, the emulsion capacity of the oil samples ranged from 79.00 (for SP) $100.00 \%$ (for ST). There were significant $(p<0.05)$ differences in the emulsion capacities of palm oil from the four processing methods. Emulsion capacity (EC) indicates a molecule's ability to act as an agent that facilitates solubilization or dispersion of two immiscible liquids (Sánchez-Zapata et al., 2009). These high levels of emulsion capacity suggest that palm oil would be highly desirable for a wide variety of both naturally occurring as well as manufactured materials in the industries such as food industries (Shahin et al., 2011). The values of the emulsion stability for the various processing methods are shown in figure 7 . The emulsion stability for freshly prepared palm oil samples ranged from 42.70 (for SP)-100.00\% (for ST). After 30 days of storage, the emulsion stability of palm oil from the four processing methods ranged from 44.93 (for SP $-100.00 \%$ (for ST). After 60 days of storage, the emulsion stability of palm oil from the four processing methods ranged from 48.77 (for SP)-100.00\% (for ST). By 90 days of storage, the emulsion stability of the oils ranged from 58.47 (for SP) $100.00 \%$ (for ST). There were significant $(p<0.05)$ differences in the emulsion stability of palm oil samples from the four processing methods. Emulsion stability (ES) is the ability to retain the integrity of an emulsion (SánchezZapata et al., 2009). The high emulsion stability also suggest that palm oil could be used for a wide variety of manufacturing processes 
especially in the food industries (Shahin et al., 2011).

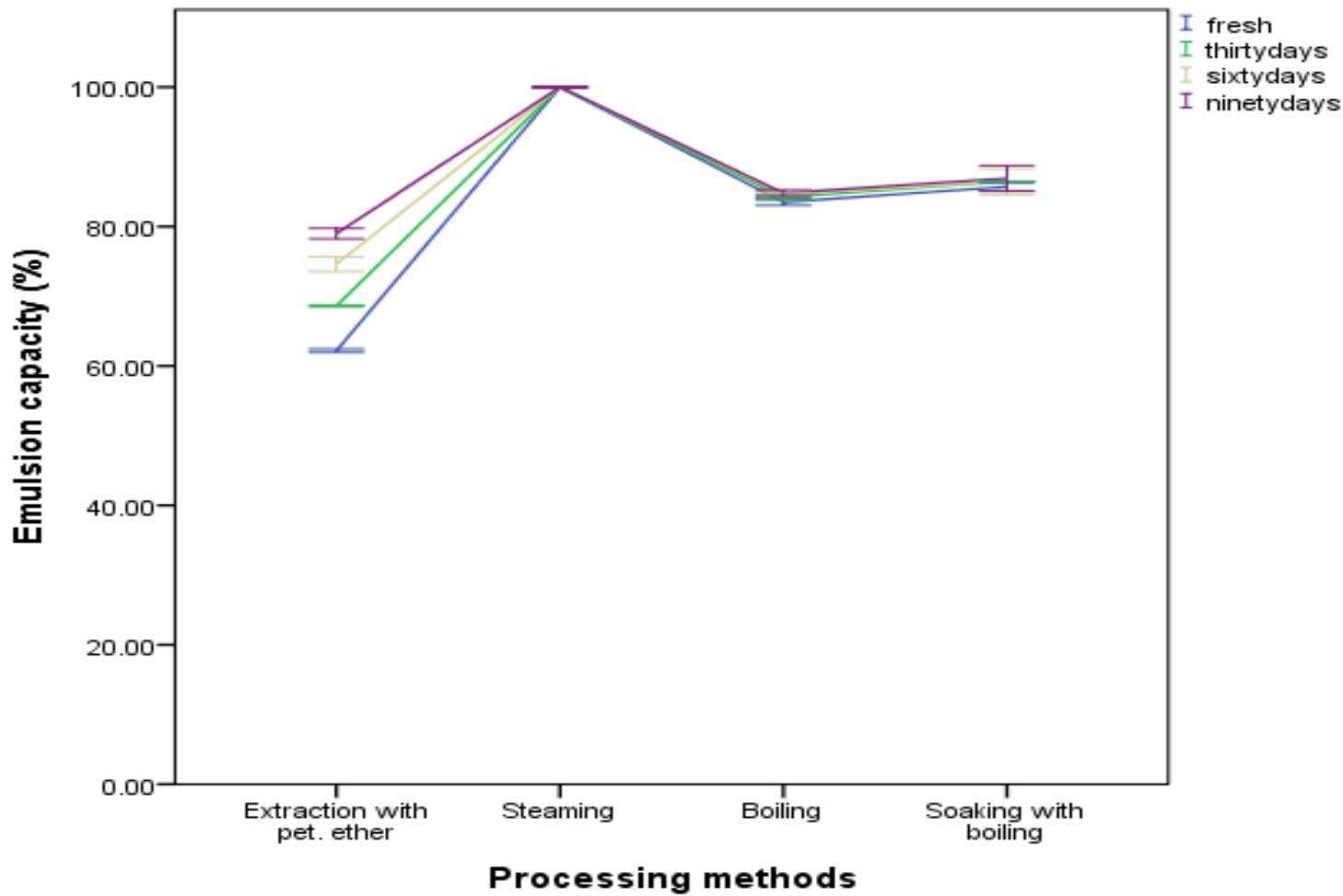

Error Bars: +/- $2 \mathrm{SD}$

Figure 6. Changes in oil emulsion capacity during short - term storage

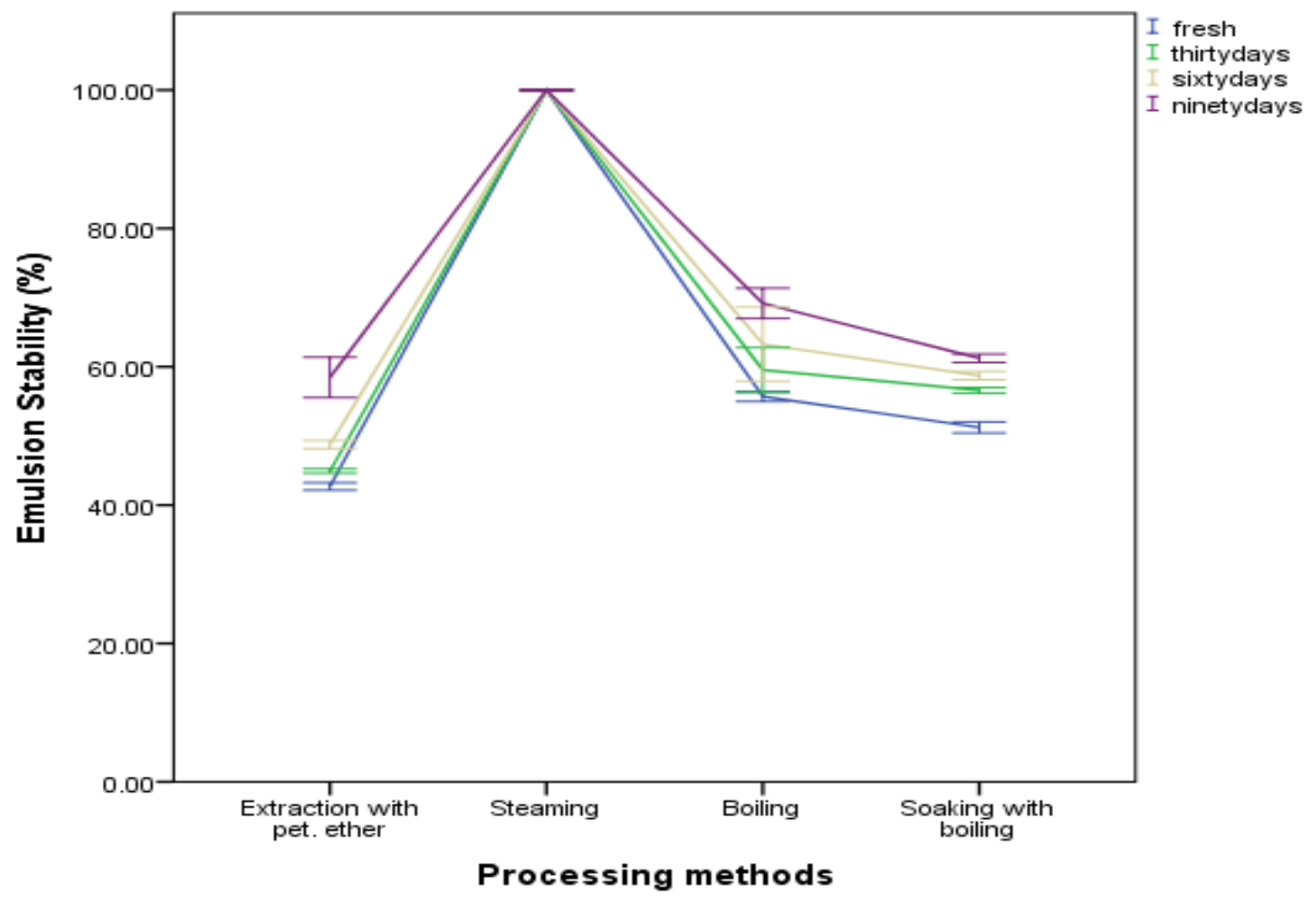

Error Bars: +/- $2 \mathrm{SD}$

Figure 7. Changes in emulsion stability of palm oil during the storage period of 90 days 


\subsection{Chemical properties of the processed palm oil}

The free fatty acid content of the processed palm oils is shown in Table 2. Free fatty acids of the freshly prepared oils from the four processing methods ranged from 5.14 (for SP) $6.54 \mathrm{mg} / \mathrm{KOH} / \mathrm{g}$ (for SWB). There were significant $(\mathrm{p}<0.05)$ differences in the free fatty acid contents at the onset (immediately after extraction). After 30 days of storage, the free fatty acids of oils from the four processing methods ranged from 8.74 (SP) - 11.41 $\mathrm{mg} / \mathrm{KOH} / \mathrm{g}$ (for SWB). There were significant $(p<0.05)$ differences among the free fatty acid content of the oils within the 30 days of storage. After 60 days of storage, the free fatty acid contents of the oils ranged from 9.26 (for SP)$13.34 \mathrm{mg} / \mathrm{KOH} / \mathrm{g}$ (for $\mathrm{SWB}$ ). There were significant $(p<0.05)$ differences among the free fatty acids after 60 days of storage. After 90 days of storage, the free fatty acids of the oils ranged from 11.46 (for SP) - $15.80 \mathrm{mg} / \mathrm{KOH} / \mathrm{g}$ (for $\mathrm{SWB})$. There were no significant $(\mathrm{p}>0.05)$ differences between samples ST and B.

Free fatty acid content is a very important quality index of oil, and should not exceed $5 \%$, (expressed as palmitic acid) (Commission du Codex Alimentarius/FAO/OMS, 2005). Fatty acids are components of triacylglycerol molecules. The presence of free fatty acid residues in palm oil indicates poor oil quality
(Agbaire, 2012). They result from lipase activity in the mesocarp of the oil palm fruit and which are responsible for the hydrolysis of triacylglycerols (Ngando et al., 2006). The high FFA level reported in this study could be linked with the postharvest handling practices employed during oil palm processing, such as period of fermentation (Ohimain et al., 2012). Ohimain and Izah (2013) have reported a fermentation period of 2-3 days after bunch welcome in a semi mechanized palm oil mill. Hartley (1988) reported that bruising of ripe oil palm fruits could raise the FFA because it contains auto-lipolytic enzymes which split the fruit oil to fatty acid and glycerol. Okechalu et al. (2011) reported that the exposure of palm fruit to sunlight prior to fermentation also enhances the formation of free fatty acids. Tagoe et al. (2012) reported that microbial invasion of the palm fruit and the FFA of the processed palm oil increases with the period of storage. Basically, FFA content of vegetable oil is an indication of the level of deterioration through the action of lipases in the fruit following cell disruption (Hiol et al., 2000; Houria et al., 2002; Ngando et al., 2011; Ohimain et al., 2012). The high FFA reported in this study could be credited to the level of exposure to sunlight, level of ripeness prior to harvesting and period of fermentation.

Table 2. Changes in the free fatty acid contents of the palm oil stored for 90 days $(\mathrm{B}=$ Boiling; $\mathrm{SWB}=$ Soaking before boiling; ST = Steaming; $\mathrm{SP}=$ Cold extraction with petroleum ether. Values shows the mean of triplicate analysis and \pm standard deviation. Values with different superscript down the column are significantly different $(\mathrm{p}<0.05))$

\begin{tabular}{|c|c|c|c|c|}
\hline Sample & Fresh & 30 days & 60 days & 90 days \\
\hline SP & $5.14^{\mathrm{a}} \pm 0.16$ & $8.74^{\mathrm{a}} \pm 0.50$ & $9.26^{\mathrm{a}} \pm 0.00$ & $11.46^{\mathrm{a}} \pm 0.42$ \\
\hline ST & $5.61^{\mathrm{b}} \pm 0.0$ & $9.82^{\mathrm{b}} \pm 0.28$ & $11.13^{\mathrm{b}} \pm 0.16$ & $13.43^{\mathrm{b}} \pm 0.06$ \\
\hline B & $6.26^{\mathrm{c}} \pm 1.16$ & $10.66^{\mathrm{c}} \pm 0.28$ & $12.34^{\mathrm{c}} \pm 0.00$ & $15.80^{\mathrm{b}} \pm 0.81$ \\
\hline SWB & $6.54^{\mathrm{d}} \pm 0.16$ & $11.41^{\mathrm{d}} \pm 0.16$ & $13.34^{\mathrm{d}} \pm 0.52$ & $15.80^{\mathrm{c}} \pm 0.16$ \\
\hline
\end{tabular}

Values shows the mean of triplicate analysis and \pm standard deviation. Values with different superscript down the column are significantly different $(\mathrm{p}<0.05)$. SP $=$ Solvent extraction; ST $=$ Steaming; $\mathrm{B}=$ Boiling; $\mathrm{SWB}=$ Soaking followed by boiling.
The peroxide value of the processed palm oils is shown in the Table 3 . The peroxide values of the freshly prepared oils for the four processing methods ranged from 2.67 (for SP) $10.07 \mathrm{meq} / \mathrm{kg}$ (for SWB). There were no significant $\quad(p>0.05)$ differences between 
samples ST and B for the peroxide value. The peroxide values for both samples SP, ST and B were below the standard $10 \mathrm{mEqkg}^{-1}$ for fresh oils. Pearson (1976) noted that fresh oil usually should have peroxide values well below 10 $\mathrm{mEqkg}^{-1}$.

The increase of peroxide value in sample SWB could be as a result processing method adopted. Peroxide value was shown by Ihekoronye and Ngoddy (1985) to be a function of processing method, storage environment and packaging. After the first 30 days of storage, the peroxide values of the four processing methods ranged from $9.80-18.20 \mathrm{meq} / \mathrm{kg}$. Sample SP had the least value $(9.80 \mathrm{meq} / \mathrm{kg})$ while sample SWB had the highest value $(18.20 \mathrm{meq} / \mathrm{kg})$.

There were significant $(p<0.05)$ differences among the peroxide values after 30 days of storage. After 60 days of storage, the peroxide values of the palm oil samples from the four processing methods ranged from 11.40 (for SP) $21.00 \mathrm{meq} / \mathrm{kg}$ (for SWB. After 90 days of storage, the peroxide values of samples from the four processing methods ranged from 14.13 (for $\mathrm{SP})-23.13 \mathrm{meq} / \mathrm{kg}$ (for SWB). There were significant $(p<0.05)$ differences among the peroxides values after 90 days of storage.

The peroxide value is an index of rancidity in oils often referred to as lipid peroxidation or oxidative degradation. It is used to measure the stability of fats by measuring the peroxides and hydro peroxides formed during the initial stages of oxidation and thus estimate the extent of spoilage of the oil. Peroxidation generates carcinogenic free radicals (Rossel, 1999). It has been shown by Ngando et al. (2011) that this value increases with storage, which suggests that sample SWB method of processing produces an oil with a shorter shelf-life.

Table 3. Changes in the peroxide value of the palm oil stored for 90 days $(\mathrm{B}=$ Boiling; $\mathrm{SWB}=$ Soaking before boiling; ST = Steaming; $\mathrm{SP}=$ Cold extraction with petroleum ether. Values shows the mean of triplicate analysis and \pm standard deviation. Values with different superscript down the column are significantly different $(\mathrm{p}<0.05))$

\begin{tabular}{|c|c|c|c|c|}
\hline Sample & Fresh & 30 days & 60 days & 90 days \\
\hline SP & $2.67^{\mathrm{a}} \pm 0.12$ & $9.80^{\mathrm{a}} \pm 0.20$ & $11.40^{\mathrm{a}} \pm 0.20$ & $14.13^{\mathrm{a}} \pm 0.12$ \\
\hline ST & $9.53^{\mathrm{b}} \pm 0.12$ & $13.20^{\mathrm{b}} \pm 0.20$ & $15.60^{\mathrm{b}} \pm 0.00$ & $17.93^{\mathrm{b}} \pm 0.12$ \\
\hline B & $9.73^{\mathrm{b}} \pm 0.12$ & $15.20^{\mathrm{c}} \pm 0.00$ & $17.80^{\mathrm{c}} \pm 0.20$ & $21.20^{\mathrm{c}} \pm 0.00$ \\
\hline SWB & $10.07^{\mathrm{c}} \pm 0.23$ & $18.20^{\mathrm{d}} \pm 0.20$ & $21.00^{\mathrm{d}} \pm 0.20$ & $23.13^{\mathrm{d}} \pm 0.12$ \\
\hline
\end{tabular}

Values shows the mean of triplicate analysis and \pm standard deviation. Values with different superscript down the column are significantly different $(\mathrm{p}<0.05) . \mathrm{Sp}=$ Solvent extraction; ST = Steaming; $\mathrm{B}=$ Boiling; SWB = Soaking followed by boiling

The saponification value of the processed palm oils is shown in Table 4. The saponification values for freshly prepared palm oil samples ranged from 194.48 (for ST) $196.82 \mathrm{mg} / \mathrm{KOH} / \mathrm{g}$ (for SWB). There were no significant $(p>0.05)$ differences among samples SP, ST and B also SP, B and SWB.

After 30 days of storage, the saponification values of the oil samples ranged from 187.00 (for ST) $-190.74 \mathrm{mg} / \mathrm{KOH} / \mathrm{g}$ (for SP). There were no significant $(\mathrm{p}>0.05)$ differences among samples SP, B and SWB after 30 days of storage. After 60 days of storage, the saponification values of the oil samples ranged from 181.86 (for sample B) - $184.66 \mathrm{mg} / \mathrm{KOH} / \mathrm{g}$ (for SWB).

There were no significant $(p>0.05)$ differences between samples SP and SWB and also between ST and B. After 90 days of storage, the saponification values of the oils ranged from 177.19 (for sample B) - $181.86 \mathrm{mg} / \mathrm{KOH} / \mathrm{g}$ (for sample SWB). There were no significant $(p>0.05)$ differences between samples SP and ST.

Saponification value is indirectly related to the molecular weights of triglycerides. It is 
inversely proportional to the average molecular weight of fatty acids (Muhammad et al., 2011).

The saponification value gives information about the solubility in water and soap formation (Akinola et al., 2010; Ohimain et al., 2013).

TZS and Codex standard requirements specify that the saponification value of unblended palm oil should be within the range 194-202 mg KOH/g oil.

The saponification values showed that the palm oils are within the range of specified standard requirements. Saponification value increases as molecular weight and chain length decreases.

Table 4. Changes in the saponification value of the palm oil stored for 90 days $(\mathrm{B}=$ Boiling; $\mathrm{SWB}=$ Soaking before boiling; $\mathrm{ST}=$ Steaming; $\mathrm{SP}=$ Cold extraction with petroleum ether. Values shows the mean of triplicate analysis and \pm standard deviation. Values with different superscript down the column are significantly different $(\mathrm{p}<0.05))$

\begin{tabular}{|c|c|c|c|c|}
\hline Sample & Fresh & $\mathbf{3 0}$ days & 60 days & 90 days \\
\hline SP & $195.88^{\mathrm{ab}^{\mathrm{b}} \pm 0.81}$ & $190.74^{\mathrm{b}} \pm 0.01$ & $184.19^{\mathrm{b}} \pm 0.81$ & $179.99^{\mathrm{b}} \pm 0.81$ \\
\hline ST & $194.48^{\mathrm{a}} \pm 0.81$ & $187.00^{\mathrm{a}} \pm 0.81$ & $182.33^{\mathrm{a}} \pm 0.00$ & $179.05^{\mathrm{b}} \pm 0.81$ \\
\hline $\mathbf{B}$ & $195.42^{\mathrm{a}} \pm 0.81$ & $189.34^{\mathrm{b}} \pm 1.40$ & $181.86^{\mathrm{a}} \pm 0.81$ & $177.19^{\mathrm{a}} \pm 0.81$ \\
\hline SWB & $196.82^{\mathrm{b}} \pm 0.81$ & $189.34^{\mathrm{b}} \pm 0.00$ & $184.66^{\mathrm{b}} \pm 0.81$ & $181.86^{\mathrm{c}} \pm 0.81$ \\
\hline
\end{tabular}

Values shows the mean of triplicate analysis and \pm standard deviation. Values with different superscript down the column are significantly different $(\mathrm{p}<0.05)$. SP $=$ Solvent extraction; ST = Steaming; $\mathrm{B}=$ Boiling; $\mathrm{SWB}=$ Soaking followed by boiling.

The iodine value of the processed palm oils is shown in the Figure 8. The iodine values for freshly extracted oil samples ranged from 49.07 (for SP) - $52.24 \mathrm{~g} / 100 \mathrm{~g}$ fat (for SWB). There were no significant $(\mathrm{p}>0.05)$ differences between samples B and SWB. The iodine values obtained for freshly prepared oil samples were within the standard range of $45-53 \mathrm{~g} / 100 \mathrm{~g}$ fat as recommended by SON (2000) and NIS (1992). After the first 30 days of storage, the iodine values of samples ranged from 52.24 (for $\mathrm{SP})-59.22 \mathrm{~g} / 100 \mathrm{~g}$ fat (for SWB). There were no significant $\quad(p>0.05)$ differences between samples $\mathrm{ST}$ and B.

After 60 days of storage, the iodine values of the oil samples ranged from 54.78 (for sample $\mathrm{ST})-61.95 \mathrm{~g} / 100 \mathrm{~g}$ fat (for sample SWB). There were no significant $(\mathrm{p}>0.05)$ differences between samples SP and B. After 90 days of storage, the iodine values of oil samples ranged from 55.41 (for sample ST) - 64.93g/100g (for sample SWB). There were significant $(\mathrm{p}<0.05)$ differences among the values.

Iodine value is the quantity of iodine absorbed by one gram of the oil to saturate the sigma bond. It is a sign of the level of unsaturation and susceptibility of oil to oxidation and rancidity (Agbaire, 2012). Iodine value determines the stability and shelf life of oil.

High iodine value makes the oil to be unstable thereby affecting other downstream application beside food (Ohimain et al., 2013).

The iodine value may be used to identify adulteration of palm oil with any other vegetable or animal fat (Ekwenye, 2006). It is a chemical parameter that characterized oil based on the level of unsaturation. Any substance, which can boost the degree of unsaturation in an oil sample, will raise the iodine value of the oil. 


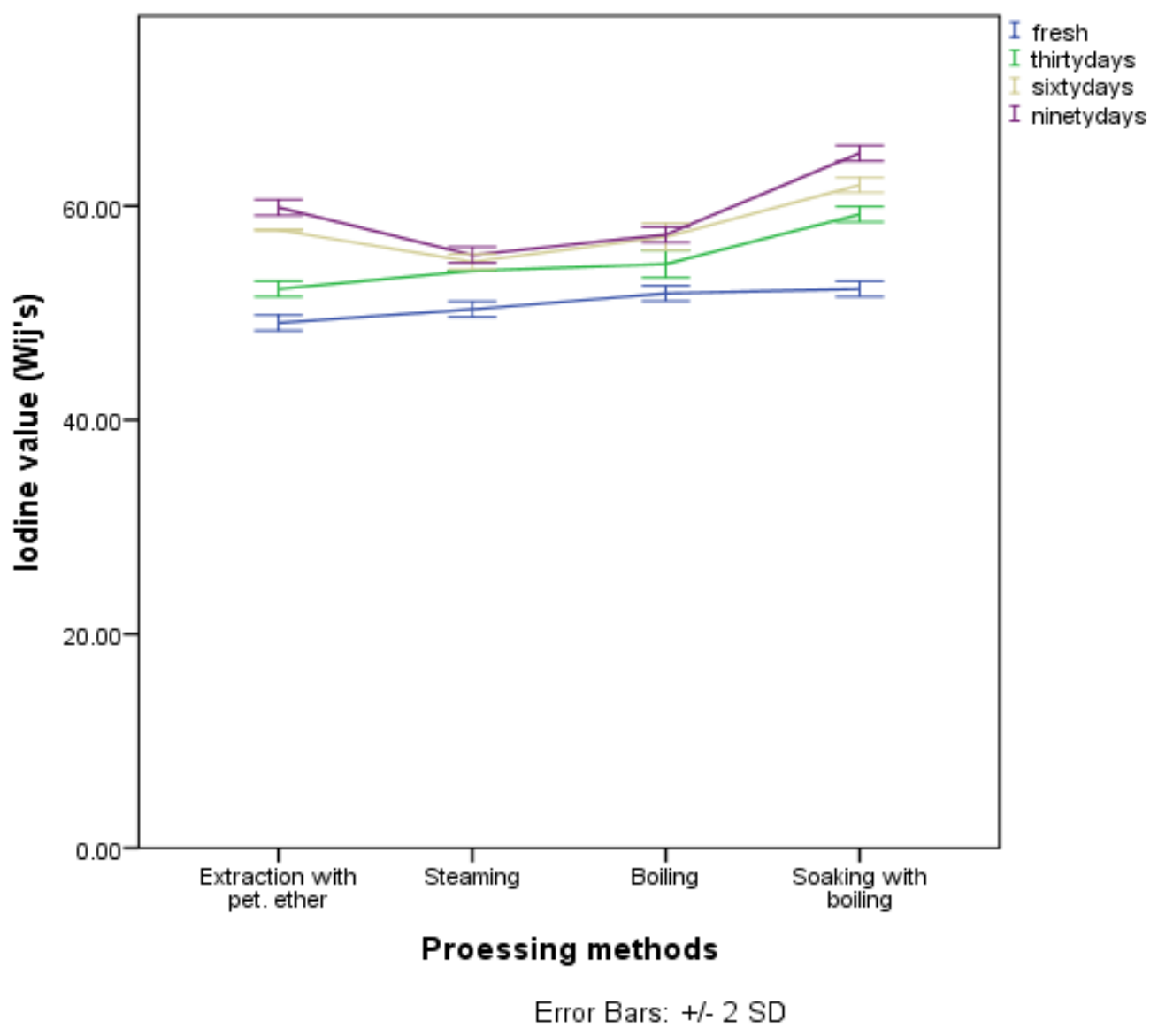

Figure 8. Changes in iodine value of palm oil during the storage period of 90 days

\subsection{Vitamin content of the processed palm oil}

Vitamin A contents of palm oil from various processing methods are shown in figure 9 . The vitamin A contents for freshly prepared oil samples ranged from 699.47 (for SWB) - 718.97 $\mathrm{IU} / 100 \mathrm{~g}$ (for SP). There were no significant $(\mathrm{p}>0.05)$ differences between ST and B and as well as B and SWB. After the first 30 days of storage, the vitamin A content of the oils ranged from 659.08 (for SWB) - 699.33 IU/100g (for SP). After 60 days of storage, it ranged from 622.05 (for sample B) - $636.41 \mathrm{IU} / 100 \mathrm{~g}$ (for sample SP). By 90 days of storage, it ranged from 581.04 (SWB) - 596.15 IU/100g (for SP). There were significant $(\mathrm{p}<0.05)$ differences among the vitamin A contents of the samples after 30,60, and 90 days of storage.
The variation in the vitamin A contents of the fresh palm oil was as a result of the processing methods employed. There were decreases in the vitamin A contents of the palm oil during storage. At room temperatures above $30^{\circ} \mathrm{C}$, phytonutrients break up (Alyssa et al., 2009). Frias et al. (2009) confirmed that the storage period has significant influence on vitamin A content. According to Duarte et al. (2011) the stability of vitamin A depends on production and storage conditions, e.g. absence of oxygen in the packaged product; storage in the absence of light and at a temperature not exceeding $30^{\circ} \mathrm{C}$. However, the values obtained for both fresh and stored palm oils were within the range of $500-2000 \mathrm{mg} / \mathrm{kg}$ set by (SON, 2000). 


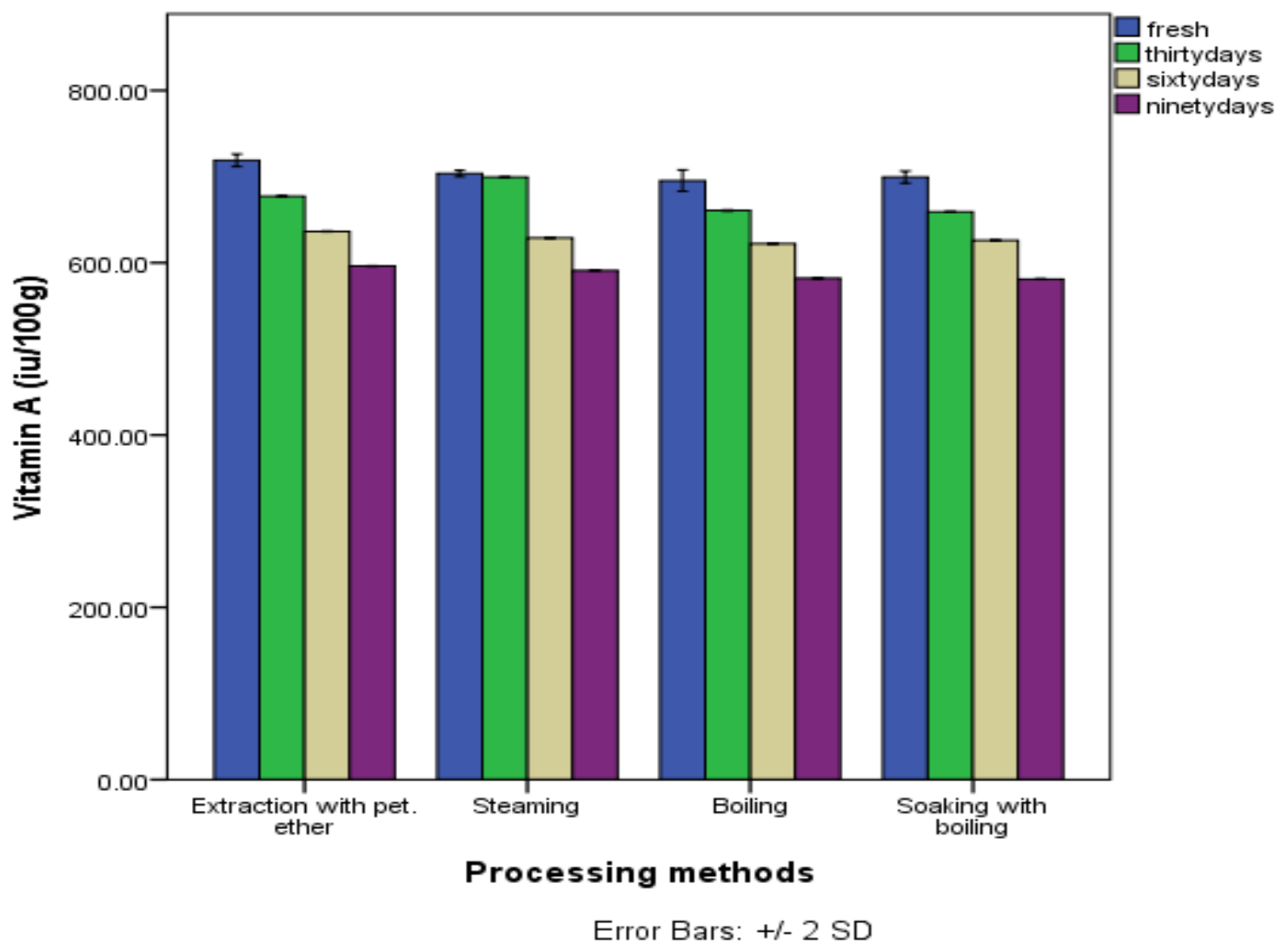

Figure 9. Changes in vitamin A of palm oil during the storage period of 90 days

The vitamin E contents of palm oil from the various processing methods are shown in figure 10. The vitamin $\mathrm{E}$ contents for freshly prepared samples ranged from 38.87 - $43.95 \mathrm{IU} / 100 \mathrm{~g}$. Sample SP had the highest value (43.95 IU/100g) while sample B had the least value (38.87 IU/100g). There were no significant $(p>0.05)$ differences between samples ST and SWB. After 30 days of storage, the vitamin E contents of oils from the four processing methods ranged from $37.65-41.65 \mathrm{IU} / 100 \mathrm{~g}$. Sample SP had the highest value (41.65 IU/100g) while sample SWB had the least values $(37.65 \mathrm{IU} / 100 \mathrm{~g})$. There were no $(\mathrm{p}>0.05)$ significant differences between samples ST and SWB. By the $60^{\text {th }}$ day of storage, the vitamin E contents of the oils ranged from $35.11-38.99$ IU/100g. Sample SP still had the highest value (38.99 IU/100g) while sample SWB had the least values (35.11 IU/100g). There were no $(p>0.05)$ significant differences between $\mathrm{ST}$ and B. By the $90^{\text {th }}$ day of storage, the vitamin $E$ contents of palm oil samples from the four processing methods ranged from $34.10-35.77$ IU/100g. Sample SP had the highest value (35.77 IU/100g) while sample SWB had the least value $(34.10 \mathrm{IU} / 100 \mathrm{~g})$. There were significant $(p<0.05)$ differences among the vitamin $\mathrm{E}$ contents of the oils after 90 days of storage.

The difference in the vitamin E contents of the fresh palm oil is also as a result of the processing methods employed. There were decreases in the vitamin E contents of the palm oil during storage. These vitamins are naturally occurring bioactive compounds which are susceptible to heat and light (Choo and Bonnie, 2000). Dominguez et al. (2014) observed that cooking loss of vitamins depends on mass transfer during thermal treatment, lead to cooking loses of vitamins. Different cooking methods affect losses in different ways. 


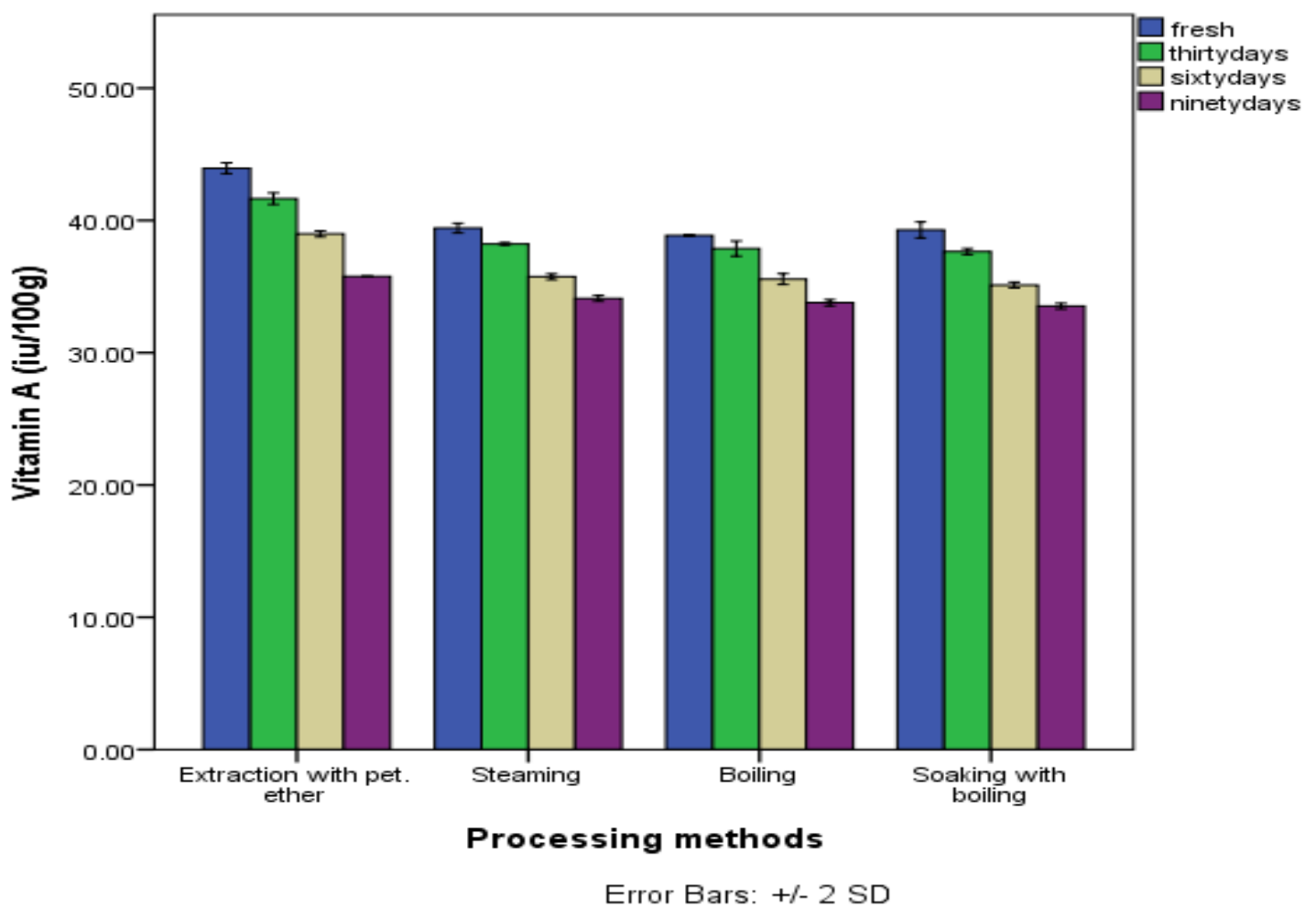

Figure 10. Changes in vitamin E of palm oil during the storage period of 90 days

\section{Conclusions}

This study has shown that the methods of palm oil processing and the storage time significantly affected the quality of oil produced. Findings from this research show that the values obtained vary with different processing techniques adopted. Extraction with petroleum ether was the best in terms of good quality, followed by steaming method and finally boiling and boiling with soaking. The quality parameters of the palm oil changed progressively with storage time. As storage time increased, free fatty acid, peroxide value and iodine value increased while saponification value decreased. The vitamins $\mathrm{A}$ and $\mathrm{E}$ contents of the palm oil changed progressively with storage time. As storage time increased, the vitamins decreased also. The physical and functional properties of the processed palm oil were also affected with storage time. Based on the discoveries from this research work, it is obvious that the samples obtained through extraction with petroleum ether and steaming were the best in terms of quality. Therefore, it is recommended to consumers for consumption. It is recommended that the storage study be extended to 6 to 12 months for further researches and the use of food grade solvents for extraction be researched on. It is also recommended that other improved methods of processing palm oil should be imbibed in order to improve the quality as well as the storage stability (shelf - life) of palm oil. Furthermore, different packaging and storage methods should be investigated, to ascertain the effects on the quality of palm oil.

\section{References}

Agbaire, P. O. (2012). Quality assessment of palm oil sold in some major markets in Delta State, southern Nigeria. African Journal of Food Sci. Technol. 3(9), 223226.

Ahsan, H., Ahad, A., Siddiqui, W. A. (2015). A review of characterization of tocopherols from plant oils and foods. Journal of Chemical Biology. 8 (2), 45 - 59.

Akinola, F. F., Oguntibeju, O. O., Adisa, A. W., Owojuyigbe, O. S. (2010). Physicochemical properties of palm oil from different palm local factories in Nigeria. 
Journal of Food Agricultural Environment 8, 264-269.

Aletor, V A., Ikhena, G. A., Egharevba, V. (1990). The quality of some locally processed Nigerian palm oil: An estimation of some critical variables. Food Chemistry, $36,311-317$.

Alina, A. R., Siti-Mashitoh, A. S., Babji, A. S., Maznah, I., Syamsul, K. M. W., Muhyiddin, Y. (2012). Oxidative stability of smoked chicken sausage substituted with red palm mid fraction during chilled storage. World Applied Sciences Journal, 17, 62-66.

Alyssa, H., Andrea, B., Carlo, P. (2009). Kinetics of tocols degradation during the Storage of Einkorn (Triticum monococcum L. spp. Monococcum) and bread wheat (Triticum aestivum L. spp. Aestivum) Flours. Journal of Food Chemistry, 116, 821- 827.

Analava, M., Sutapa, M. (2009). Health Effects of Palm Oil. Journal of Human Ecology, 26(3), 197-203.

Appelqvist, L. A., Ohlson, R. (1972). Rapeseed cultivation, composition, processing and utilization, edited by L.A. Appelqvist and R. Ohlson, Elsevier, Publishhing Co., Amsterdam, pp. 60.

Babatunde, O. O. (1987). Sterilisation and mechanical digestion of oil palm fruit, unpublished Ph.D. Thesis, Obafemi Awolowo University, Ile-Ife, Nigeria.

Bazlul Mobin Siddique, A. A., Mohamad, H. I., Sufia Hena, A., Ka, M. (2010). Physicochemical properties of blends of palm olein with other vegetable oils. grasas y aceites. octubre-diciembre, 61(4), 423-9.

Choo, Y. M., Bonnie, T. Y. P. (2000). Valuable minor constituents of commercial red palm olein: carotenoids,vitamin E ubiquinones and sterols. Journal of Oil Palm Research. 12, 14-24.

Commission du Codex Alimentarius/ FAO/OMS, (2005). Normes alimentaires pour huiles et graises. CODEXSTAN 210, $\mathrm{FAO} / \mathrm{OMS}$.

De Marco, E., Savarese, M., Parisini, C., Battimo, I., Falco, S., Sacchi, R. (2007). Frying performance of a sunflower/palm oil blend in comparison with pure palm oil. European Journal of Lipid Science and Technology. 2007; 109, 237-246.

Denenu, E. O., Eze, J. N. (1983). The quality of locally processed palm oil. A comparison of processing methods. Nigerian. Food Journal pp. 123-127.

Dominguez, R, Gomez, M., Fonseca, S., Lorenzo, J. M. (2014). Effects of different cooking methods on lipid oxidation and formation of volatile compounds in foal meat. Meat Science. 97, 223-230.

Duarte-Favaro, R. M. D., Iha, M. H., Mazzi, T. C., Favaro, R., Bianchi, M. D. P. (2011). Stability of vitamin A during storage of enteral feeding formulas. Food chemistry, 126(3), pp. 827-830.

Ekwenye, U. N. (2006). Chemical characteristics of palm oil biodeterioration. BIOKEMISTRI 18(2): 141-149 (December 2006) http://www.bioline.org.br/bk Embrandiri, A., Ibrahim, M. H., Singh, R. P. (2013). Palm oil mill wastes utilization; sustainability in the Malaysian Context. IJSRP. 3(3), 1-6.

Frias, J., Peňas, E., Vidal-Valverde, C. (2009). Changes in vitamin content of powder external formula as a consequence of storage, Food Chemistry, 115, 1411-1416.

Gan Peck Yean, L.Z.D. (2012). A study on Malaysia palm oil position in the world market to 2035. IEEJ. Jun 2012.

Gee, P. T. (2007). Analytical characteristics of crude and refined palm oil and fractions. European Journal of Lipid Science and Technology. 2007; 109, 373-379.

Grapevine, F. (2008). News from Nyaru Menteng - Comings and goings at Nyaru Menteng. Edition 17. Borneo Orangutan Survival. Source: Green, J. P. Mamalis, S. Marcinkicwicz.

Hartley, C. W. S. (1988). The Oil Palm. Longman Publishers Inc. New York, pp. $703-712$.

Hiol, A., Comeau, L. C., Druet, D., Jonzo, M. D., Rugani, N., Sarda, L. (2000). Purification and characterization of an extracellular lipase from a Thermophilic rhizopus oryzae strain isolated from palm 
fruit. Enzyme Microb. Technol. 31, 968 975.

Houria, A., Comeau, L., Deyris, V., Hiol, A. (2002). Isolation and characterization of an extra-cellular lipase from Mucor sp. Strain isolated from palm fruit. Enzyme Microb. Technol. 31, 968-975.

Ihekoronye, A. I., Ngoddy, P. O. (1985). Integrated food Science and technology for the tropics. Macmillan Publishers Ltd. London, pp. 236-254.

Izah, S.C., Ohimain, E.I. (2013). Microbiological quality of crude palm oil produced by smallholder processors in the Niger Delta, Nigeria. Journal of Microbiology and Biotechnology Research, 3 (2), 30 - 36.

Kirk, R. S., Sawyer, R. (1991). Pearson's Composition and Chemical Analysis of Foods, 9th Edition. Longman Scientific \& Technical, Essex, England.

Madubuike, P. C., Ezigbo, I. J., Ekpe, I. O., Onwukwube, S. I. (2015). Evaluation of the quality and level of adulteration of palm oil obtained from different locations in Enugu metropolis, Nigeria. International Journal of Multidisciplinary Science and Engineering, Vol 6 (6), pp. 23-26.

Muhammad, N. E., Bamishaiye, O., Bamishaiye, L., Usman, M., Nafiu, O., Oleyede, B. (2011). Physicochemical prop. And fatty acid composition of Dennatia tripetala fruit oil (pepper fruit) Niger. Journal of Biochemistry Mol. Biol; 24, 4246.

Ngando, E. G. F., Dhouib, R., Camiere, F., Amvam Zollo, P. H., Arondel, J. (2006). Assaying lipase activity from oil palm fruit (Elaeis guineensis jacq) mesocarp. Plant Physiology and Biochemistry, 44, 611-617

Ngando, E. G. F., Mpondo, E. A., Dikotto, E. E. L., Koona, P. (2011). Assessment of the quality of crude palm oil from small holders in Cameroon, Journal of Stored Products and Post-Harvest Research, 2: 52-58.

Nigerian Industrial Standards, (N.I.S). (1992). "Standards for Edible vegetable oil", pp. 512.
Oguntibeju, O. O., Esterhuyse, A. J., Truter, E. J. (2009). Red palm oil: nutritional, physiological and therapeutic roles in improving human wellbeing and quality of life. British Journal of Biomedical Science, 66(4), 216-222.

Ohimain, E. I., Izah, S. C., Fawari, A. D. (2013). Quality Assessment of Crude Palm Oil Produced by Semi-Mechanized Processor in Bayelsa State, Nigeria. Discourse Journal of Agriculture and Food Sciences, 1 (11), 34 $-46$.

Ohimain, E. I., Daokoru-Olukole, C., Izah, S. C., Alaka, E. E. (2012). Assessment of the quality of crude palm oil produced by smallholder processors in Rivers State, Nigeria. Niger Journal of Agricultural Food Environment, 8(2), 28 - 34

Ohimain, E. I., Izah, S. C. (2013). Energy selfsufficiency of smallholder oil palm processing in Nigeria. Renewable Energy, $63,426-431$.

Okechalu, J. N., Dashen, M. M., Lar, P. M., Okechalu, B., Gushop, T. (2011). Microbiological quality and chemical characteristics of palm oil sold within Jos Metropolis, Plateau State, Nigeria. Journal of Microbiology and Biotechnology Research, 1(2), 107-112.

Orji, M. U., Mbata, T. I. (2006). "Effects of Extraction Methods on the quality and spoilage of Nigerian palm oil", African Journal of Biochemistry Res. Vol. 2(9), pp.192-196, 2006.

Owolarafe, O. K., Faborode, M. O., Ajibola, O. O. (2002). Comparative evaluation of the digester-screw press and hand-operated hydraulic press for oil palm fruit processing. Journal of Food Engineering 52, 249-255.

Pearson, D. (1976). The chemical analysis of food. $7^{\text {th }} \mathrm{Ed}$. Church hill Livingstone. Longman Grp Ltd. London, pp. 4-513.

Pike, O. A. (2003). Fat characterization in food analysis. Third Edition. Kluwer academic Plenum publishers. New York. pp. 229-245.

Poku, K. (2002). "Small scale palm oil processing Africa", Agriculture and Consumer Protection.F.AO. Agricultural Services Bull. pp. 62-148. 
Sánchez-Zapata, E., Fuentes-Zaragoza, E., Fernández-López, J., Sendra, E., Sayas, E., Navarro, C., Pérez-Alvarez, J. A. (2009). Preparation of dietary fiber powder from tiger nuts (Cyperus esculentus) milk ("horchata") by-products and its physicochemical properties. Journal of Agriculture \& Food Chemistry, 57, 77197725.

Shahin, M., Hady, S. A., Hammad, M., Mortada, N. (2011). Development of stable $\mathrm{O} / \mathrm{W}$ emulsions of three different oils. International Journal of Pharmaceutical Studies and Research Vol. II/ Issue II, 4551.

Standard Organization of Nigeria (S.O.N) (2000). Standards for edible refined palm oil and its processed form. pp. 2-5.

Sundram, K., Sambanthamurthi, R., Tan, Y. A. (2003). Palm fruit chemistry and nutrition. Asia Pacific Journal of Clinical Nutrition 12, 355-362.

Tagoe, S. M. A., Dickinson, M. J., Apetorgbor, M. M. (2012). Factors influencing quality of palm oil produced at the cottage industry level in Ghana. International Food Research Journal. 19 (1), 271 - 278.

Udensi, E. A., Iroegbu, F. C. (2007). Quality assessment of palm oil sold in Major markets in Abia State, Nigeria. AgroScience, 6(2): $25-27$.

Zu, K.S.A., Adjei-Nsiah, S., Bani, R. J. (2012) Effect of processing equipment and duration of storage of palm fruits on palm oil yield and quality in the Kwaebibrem District, Ghana. Agric. Res. Rev 1(1), 18 - 25. 